\section{Registration of ICGV-SM 83708 Peanut Germplasm}

ICGV-SM 83708 (Reg. no. GP-68, PI 585000), an improved peanut (Arachis hypogaea L. subsp. hypogaea Krap \& Rig. var. hypogaea Greg.) germplasm, was developed at the Asia Center of the International Crops Research Institute for the Semi-Arid Tropics (ICRISAT), Patancheru, India. It was introduced into the SADC (Southern African Development Community)/ICRISAT Groundnut Project, Malawi, in 1982 as an advanced breeding line. After initial evaluation in the 1982-1983 crop season in Malawi, it was included in the SADC regional groundnut varietal trial in 1983-1984 as ICGMS 42. Subsequently, it was redesignated ICGV-SM 83708. After extensive evaluation in regional, national, and on-farm trials, it was released in 1990 as ' $\mathrm{CG} 7$ ' in Malawi, and in 1991 as 'MGV 4' in Zambia. It is particularly well adapted to the central plateau of Lilongwe and Kasungu, low-lying areas of Salima and Chitipa, and the Karonga plains in Malawi, and to the Eastern Province areas of Zambia. It is suitable for red skin and confectionery trades because of its red testa color, uniform seed size, and ease in blanching.

ICGV-SM 83708 originated from a single $\mathrm{F}_{2}$ plant selection in a cross of USA $20 /^{\circ} \mathrm{TMV} 10^{\prime}$ ' in 1977-1978. USA 20, an unknown germplasm line introduced from the USA into India and renamed in India, belongs to the virginia (subsp. hypogaea var. hypogaea) botanical group, runner growth habit. TMV 10 , a natural mutant selected from an unknown variety introduced to India from Argentina that belongs to the virginia botanical group and has a bunch growth habit, is a widely adapted cultivar released in India in 1970 (1). Phenotypically similar $F_{3}$ progenies of the $F_{2}$ plant were selected and bulked at harvest. This process of bulking the phenotypically similar plants was repeated in successive generations until the bulk was phenotypically homogeneous. The pedigree of ICGV-SM 83708 is (USA 20/TMV 10) $\mathrm{F}_{2}-\mathrm{P}_{3}-\mathrm{B}_{1}-\mathrm{B}_{1}-\mathrm{B}_{1}-\mathrm{B}_{1}-\mathrm{B}_{1}-\mathrm{B}_{1}-\mathrm{B}_{1}-\mathrm{B}_{1}$.

ICGV-SM 83708 has an erect to Decumbent 3 growth habit, with alternate branching and elliptical dark green, medium-sized leaves (2). It matures in approximately $135 \mathrm{~d}$ in Malawi and Zambia. It has mostly two-seeded pods, characterized by a slight beak, moderate to deep constriction, moderate reticulation, and no or slight ridges. One- and three-seeded pods occur occasionally. The average pod length is $41 \mathrm{~mm}$, and average pod breadth is 14 $\mathrm{mm}$. The testa of ICGV-SM 83708 is red in color. Its average meat content varies from 68 to $74 \%$, and the average 100 -seed mass from 61 to $64 \mathrm{~g}$, depending on the location in which it is grown in the region. Oil content averages $470 \mathrm{~g} \mathrm{~kg}^{-1}$ in Malawi. The oleic/ linoleic fatty acid ratio of ICGV-SM 83708 (1.88) is superior to that of Malawi cultivars Chalimbana (1.20), Chitembana (1.64), Mani Pintar (1.43), and Mawanga (1.58). The seeds are of uniform size and shape; very few have flat end surfaces. Unlike Chalimbana, the seed of ICGV-SM 83708 blanches easily.

ICGV-SM 83708 was compared with local cultivars Chalimbana, Chitembana, Mani Pintar, and Mawanga in different yield trials during the 1983-1984 to 1991-1992 seasons in Malawi. It produced an average pod yield of $3.35 \mathrm{t} \mathrm{ha}^{-1}$ compared with 2.48 $t$ of Chalimbana in 14 trials, $2.39 t$ compared with $2.16 t$ of Mawanga in 10 trials, $1.96 \mathrm{t}$ compared with $1.64 \mathrm{t}$ of Chitembana in 5 trials, and $2.61 \mathrm{t}$ compared with $2.25 \mathrm{t}$ of Mani Pintar in 6 trials. The pod yield advantage of ICGV-SM 83708 over these cultivars ranged from 11 to $35 \%$ (3). In Zambia, 1CGV-SM 83708 was compared with 'Makulu Red' for five seasons (1983-1984, and $1985-1986$ to $1988-1989$ ) in 10 trials, and averaged $10 \%$ more pod yield than Makulu Red, which produced $1.75 \mathrm{t} \mathrm{pod} \mathrm{ha}^{-1}$ (3).
ICGV-SM 83708 is as susceptible to early leaf spot (caused by Cercospora arachidicola $\mathrm{S}$. Hori) and rosette disease as local cultivars Chalimbana in Malawi, and Makulu Red in Zambia. It is also susceptible to rust (caused by Puccinia arachidis Speg.) and late leaf spot [caused by Phaeoisariopsis personata (Berk. \& M.A. Curtis) Arx; syn. Cercosporidium personatum (Berk. \& M.A. Curtis) Deighton], with disease reactions similar to Kadiri 3 in India.

Breeder seed of ICGV-SM 83708 is maintained by the SADC/ ICRISAT Groundnut Project, Malawi. Limited quantities of seed are also available upon request from the Genetic Resources Division, ICRISAT Asia Center. Seeds of ICGV-SM 83708 are also deposited with the National Seed Storage Laboratory, 1111 Mason St., Fort Collins, CO 80521-4500.

\section{S. N. Nigam, ${ }^{*}$ G. L. Hildebrand, AND K. R. BOCK}

\section{References and Notes}

1. Basu, M.S., and Reddy, P.S. 1987. Groundnut varieties of India. Tech. Bull. 2. Natl. Res. Ctr, for Groundnut, Indian Council of Agric. Res., Junagadh, Gujarat, India.

2. International Board of Plant Genetic Resources and International Crops Research Instibute for the Seni-Arid Tropics. 1992. Descriptors for groundnut. IBPGR, Rome, and ICRISAT, Patancheru, AP, India.

3. International Crops Research Institute for the Semi-Arid Tropics. 1994. Groundnut Elite Germplasm ICGV-SM 83708. ICRISAT Plant Material Description no. 51. ICRISAT, Patancheru, AP, India.

4. S.N. Nizam, Genetic Enhancement Div., ICRISAT Asia Ctr., Patanchen 502324 , AP, India; G.L. Hildebrand, SADC/ICRISAT Groundnut Project, Chitedze Agric. Res. Stn., P.O. Box 1096, Lilongwe, Malawi; K.R. Bock, P.O. Box 641, Ukunda, Mombasa, Kenya. Contribution of SADC/ ICRISAT Groundnut Project, Lilongwe, and ICRISAT Asia Ctr., Patancheru. ICRISAT Journal Article no. 1645. Registration by CSSA. Accepted 28 Feb. 1995. *Corresponding author (Email: icrisat@cgnet.com).

The authors wish to thank Drs. A.J. Chiyembekeza and P.K. Sibale, and $\mathrm{Mr}$ H.K. Mande of Malawi, and Mr. M.B. Syamasonta and Dr. J.M. Mulila of Zambia for conducting SADC regional groundnut variety trials, and national and on-farm trials in their respective countries.

Published in Crop Sci. 35:1718 (1995).

\section{Registration of an Early-Maturing Peanut Germplasm ICGV 86015}

ICGV 86015, a spanish-type peanut (Arachis hypogaea L. subsp. fastigiata Waldron var. vulgaris Harz) germplasm (Reg. no. GP-73, PI 585005) was bred at the Asia Center of the International Crops Research Institute for the Semi-Arid Tropics (ICRISAT), Patancheru, India. It was identified and released as an early-maturing widely adapted high-yielding breeding line (3) by the Plant Materials Identification Committee of ICRISAT in 1993. This improved germplasm has been designated as Hung Loc 25 (HL 25) in Vietnam, where, in 33 field experiments and 6 trials involving 344 farming families, it was found most suitable for intercropping with cassava (Manihot esculenta Crantz) and maize (Zea mays L.) in the southeast coastal and southeastern regions of the country (4). It is proposed for release as BARD 92 in Pakistan for double cropping with wheat (Triticum aestivum L.) and is particularly adapted to the barani (rainfed) conditions of the Pothwar area in the country (1).

ICGV 86015 [also known as ICGS(E) 56] originated from a cross made in the 1981-1982 postrainy season between 'ICGS 44' and TG 2E. ICGS 44 (PI 537112) is a high-yielding, mediummaturity cultivar released in 1988 for postrainy season cultivation 
in India as ICGV 87128 (5). TG 2E is an early-maturing breeding line developed at the Bhabha Atomic Research Center, Trombay, Bombay, India, from a cross of Dwarf Mutant with TG 3 (6). ICGV 86015 was bred following the bulk pedigree method. In the $F_{2}$ generation, selected phenotypically similar plants were bulked together at harvest and the first selected bulk was designated as $B_{1}$. The bulk was again grown and the process of bulking of selected phenotypically similar plants was repeated until the $F_{8}$ generation, when the selected bulk was phenotypically homogeneous. The pedigree of ICGV 86015 is ICGS $44 /$ TG $2 E-\mathrm{F}_{2}-\mathrm{B}_{1}-\mathrm{B}_{2}-\mathrm{B}_{1}-\mathrm{B}_{1}-\mathrm{B}_{1}$.

ICGV 86015 has performed well across many countries. In Vietnam, it produced 2.0 to $2.8 \mathrm{t}$ pods ha ${ }^{-1}$, outyielding the local control cultivar Giay by 17 to $25 \%$. In Pakistan, it averaged $18 \%$ more pod yield than the local cultivar Banki, which averaged 1.36 $\mathrm{t} \mathrm{ha} \mathrm{a}^{-1}$ of pod yield in 10 trials during 1985 to 1990 . In 1ndia, ICGV 86015 averaged $15 \%$ more pod yield than the popular cultivar JL 24, which produced an average pod yield of $1.70 \mathrm{t} \mathrm{ha}^{-1}$ in 31 multilocational evaluations during the period from 1984 to 1988. In Nepal, it yielded an average $2.67 \mathrm{t} \mathrm{ha}^{-1}$ of pods, $57 \%$ more than 'B 4' in 51 sets of farmers' field trials. In the international trials organized by ICRISAT, ICGV 86015 had a pod yield of $2.93 \mathrm{tha}^{-1}$ in Bangladesh, $3.18 \mathrm{tha}^{-1}$ in Sri Lanka, 2.95 $\mathrm{tha}^{-1}$ in the Philippines, $2.69 \mathrm{tha}^{-1}$ in Thailand, $2.20 \mathrm{tha}^{-1}$ in Mozambique, $3.76 \mathrm{tha}^{-1}$ in Haiti, $3.32 \mathrm{tha}^{-1}$ in Gabon, and 4.29 $\mathrm{t} \mathrm{ha}^{-1}$ in Ghana. In these countries, ICGV 86015 produced 15 to $66 \%$ more pod yield than the best control cultivar in each respective country.

In the rainy season at ICRISAT Asia Center, ICGV 86015 matures in 100 to 105 days after planting (DAP), taking 15 to 20 $\mathrm{d}$ less than the medium-maturity cultivars. In Pakistan, it matures in 120 to 130 DAP, taking 50 to $60 \mathrm{~d}$ less than the local cultivar Banki. In Vietnam, it matures in 92 to $98 \mathrm{~d}$ in the rainy or summer-autumn season and in 88 to $93 \mathrm{~d}$ in the winter-spring season, similar to that of the local control cultivars Giay and Ly. ln other countries its maturity ranges from $85 \mathrm{~d}$ in Ghana to 134 $\mathrm{d}$ in Mozambique.

At ICRISAT Asia Center, ICGV 86015 has erect growth habit, with sequential branching and elliptical dark green, medium-sized leaves (2). The number of primary branches ranges between 4 and 8 , and of secondary branches between 0 and 4 . Its main stem is approximately $22 \mathrm{~cm}$ long with a canopy width of approximately $43 \mathrm{~cm}$. Its pods are mainly two-seeded, small to medium in size (26 $\mathrm{mm}$ average length, $13 \mathrm{~mm}$ average breadth) with no or slight beak and constriction, and smooth to slightly reticulated. It has $69 \%$ meat content. Its seeds are tan in color, weigh $48 \mathrm{~g} 100$ seed ${ }^{-1}$, and contain $480 \mathrm{~g} \mathrm{~kg}^{-1}$ oil and $240 \mathrm{~g} \mathrm{~kg}^{-1}$ protein.

Breeder seed of ICGV 86015 is maintained by the Genetic Resources Division, ICRISAT Asia Center. Limited quantities of seed are available upon request. Seeds of ICGV 86015 are also deposited with the National Seed Storage Laboratory, 1111 Mason St., Fort Collins, CO 80521-4500.

$$
\begin{array}{r}
\text { S. N. Nigam, M. J. V. RAO, H. D. UPADHYAYA, }{ }^{*} \\
\text { Y. L. C. RAO, AND N. S. RedDY (7) }
\end{array}
$$

\section{References and Notes}

1. Ali, N., S.N. Malik, and Anis-ur-Rehman. 1992. Proposal for approval of short-duration groundnut variety (BARD 92). Submitted to the Variety Evaluation Committee (VEC), Pakistan Agric. Res. Council (PARC), Islamabad, Pakistan. Barani Agric. Res. \& Develop. Program.

2. International Board of Plant Genetic Resources and Intemational Crops Research Instinute for the Semi-Arid Tropics. 1992. Descriptors for groundnut. IBPGR, Rome, and ICRISAT, Patancheru, AP, India.

3. International Crops Research Instinute for the Semi-Arid Tropics. 1994. Groundnut elite germplasm ICGV 86015. ICRISAT Plant Material Description no. 50. ICRISAT, Patancheru, AP, India.
4. Ngoc, P.V., H. Kim, and M.V. Quyen. 1993. Two new high-yielding groundnut varieties; Hung Loc 25 and Hung Loc 28 and technology package. Bull. Inst. Agric. Sci., Ho Chi Minh City, Vietnam.

5. Nigam, S.N., S.L. Dwivedi, Y.L.C. Rao, and R.W. Gibbons. 1990. Registration of ICGV 87128 peanut cultivar. Crop Sci. 30:959.

6. Patil, S.H., and C. Mouli. 1981. Groundnut Research in Bhabha Atomic Research Center. p. 1-2. In Annu. Prog. Rep. Groundnut Res., Kharif 1980-81. Part 3. All India Coordinated Res. Project on Oilseeds (AICORPO). Directorate of Oilseeds Res., Rajendranagar, Hyderabad, India.

7. S.N. Nigam, H.D. Upadhyaya, Y.L.C. Rao, and N.S. Reddy, Genetic Enhancement Div., ICRISAT Asia Ctr., Patancheru P.O., Andhra Pradesh 502 324, India; M.J.V. Rao (former ICRISAT staff), ICI Ltd., Agric. Res. Sm., Begur, Bangalore, Kamataka 560068 , India. ICRISAT Joumal Article no. 1647. Registration by CSSA. Accepted 28 Feb. 1995. *Corresponding author (Email: icrisat@cgnet.com).

The assistance of the Project Director, Directorate of Oilseeds Research, Rajendranagar, Hyderabad, India, various AICORPO scientists in India, and scientists in other countries in evaluating ICGV 86015 is gratefully acknowledged.

Published in Crop Sci. 35:1718-1719 (1995).

\section{Registration of KY 83C-16-2 Wheat Germplasm}

KY 83C-16-2 (Reg. no. GP-424, PI 586687) is a soft red winter wheat (Triticum aestivum L.) developed by the Kentucky Agricultural Experiment Station, and released in 1994. KY 83C-16-2 was derived from a single head selection in the $\mathrm{F}_{2}$ generation of the cross IN65309C1-182-3/1L 77-2756//IN65309C1-182-3/' Florida 302 '. A combination of pedigree and bulk selection methods were used in subsequent generations. Breeder seed consisted of the bulk of $58 \mathrm{~F}_{10}$ headrows. KY $83 \mathrm{C}-16-2$ was tested in the state variety trial at seven locations in Kentucky from 1991 to 1994 and in the Uniform Eastern Soft Red Winter Wheat Nursery from 1993 to 1994. Grain yield has averaged $105 \%$ of 'Cardinal' and $98 \%$ of 'Clark'. Test weight of KY 83C-16-2 was good, averaging $\approx 102 \%$ of Clark. In 1994, KY 83C-16-2 was increased for possible cultivar release. While exhibiting outstanding yield potential in certain environments, its yield performance was more erratic than desired in a cultivar.

KY 83C-16-2 should provide useful germplasm for breeders in the eastern wheat region because of its combination of excellent winterhardiness, short stature and lodging resistance, superior test weight and good overall disease resistance. $\mathrm{KY} 83 \mathrm{C}-16-2$ has excellent resistance to powdery mildew [caused by Erysiphe graminis (DC.) f. sp. tritici Ém. Marchal], and septoria blotch [caused by Septoria tritici Roberge ex Desmaz.]. KY 83C-16-2 is moderately resistant to glume blotch [caused by Phaeosphaeria nodorum (E. Müller) Hedjaroude], and moderately susceptible to leaf rust (caused by Puccinia recondita Roberge ex Desmaz. f. sp. tritici Eriks. \& E. Henn.). KY $83 \mathrm{C}-16-2$ is susceptible to all biotypes of the Hessian fly [Mayetiola destructor (Say)].

KY $83 \mathrm{C}-16-2$ is a white-chaffed, awnletted soft red winter wheat with compact spikes and intermediate size kernels. It is late maturing, with a heading date equivalent to that of Cardinal and $\approx 5$ d later than Clark. KY 83C-16-2 is similar in height to 'Saluda', with excellent straw strength and lodging resistance. Winterhardiness of KY 83C-16-2 is excellent, equivalent to that of ' 2510 '.

The breeding research that generated this germplasm was supported in part by the Kentucky Small Grain Growers Association-Kentucky Smail Grain Promotion Council. Seed will be maintained by the Kentucky Agricultural Experiment Station. Small quantities of seed are available upon request from the corresponding author.

D. A. Van Sanford, * W. L. Pearce, C. S. Swanson, C. R. TutT, L. J. TOMES, AND D. E. Hershman (1) 